\title{
Articles
}

\section{Understanding the Japanese Keiretsu: Overlaps Between Corporate Governance and Industrial Organization}

\author{
Ronald J. Gilson ${ }^{\dagger}$ and Mark J. Roe ${ }^{\dagger t}$
}

\section{CONTENTS}

I. The Berle-Means Model of AMERICAN CoRporate Governance . . . . . 876

II. The Japanese Main Bank as the Missing Monitor . . . . . . . . . . . 879

III. The Japanese System as Global Contractual Governance of Which SPECIFIC CoRPorate GovernancE is A SUbSET $\ldots \ldots \ldots \ldots \ldots \ldots . \ldots 82$

A. A Stylized Model of the Japanese System . . . . . . . . . . 884

1. The Continuum: Contract Versus Organization .......... 884

2. Japan: A Hybrid Between Contract and Organization .......885

3. Illustration: General Motors and Fisher Body .......... 889

$\dagger$ Charles J. Meyers Professor of Law and Business, Stanford University, and Professor of Law, Columbia University.

tt Professor of Law, Columbia University. We are grateful to Bernard Black, John C. Coffee, Jr., Victor Goldberg, Jeffrey Gordon, Henry Hansmann, Hideki Kanda, Steven N. Kaplan, W. Carl Kester, Louis Lowenstein, Roberta Romano, Mark Wolfson, and participants at the Conference on Corporate Governance: New Problems and New Solutions, Center for Economic Policy Research, Stanford University, April 16-17, 1992, and at the University of Michigan Law School Law and Economics Workshop, for helpful comments on earlier drafts of this Article. An informal seminar series on comparative corporate governance sponsored by Columbia University's Law and Economics Center led to our collaboration on this Article. 
.B. But What About Monitoring? Product Market Competition as the

Catalyst that Makes the Hybrid Work . . . . . . . . . . . 891

1. Competition as Catalyst ................... 891

2. Vertical and Horizontal Keiretsu: Helping to Explain Some

Performance Differences . . . . . . . . . . . . . . . 894

3. Is Competition Enough? ................. 895

IV. IMPLICATIONS FOR COMPARATIVE CORPORATE GOVERNANCE ANALYSIS $\ldots .895$

A. Implications for Understanding the Japanese Corporate

Governance System . . . . . . . . . . . . . . . . 896

1. Understanding the Role of the Main Bank ........... 896

2. Understanding the Significance of Cross-Holdings'

Antitakeover Role . . . . . . . . . . . . . . . . . . . . . . . . . 897

3. Understanding Japanese Contract ............... 899

4. Understanding the Role of Public Shareholders in Japan . . . . . 900

5. Understanding the Stability of the Contractual

Governance Model ...................... 901

B. Evaluating Reform Proposals for the U.S. Corporate

Governance System .....................901

1. The Keiretsu and the $L B O$ Association ............. 902

2. Where Might the Japanese Model Provide Guidance? ........ 904

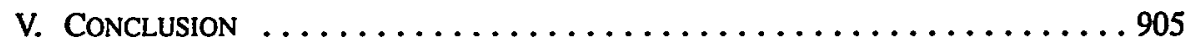

We aim here for a better understanding of the Japanese keiretsu. Our essential claim is that to understand the Japanese system-banks with extensive investment in industry and industry with extensive cross-ownership-we must understand the problems of industrial organization, not just the problems of corporate governance. The Japanese system, we assert, functions not only to harmonize the relationships among the corporation, its shareholders, and its senior managers, but also to facilitate productive efficiency.

Comparative corporate governance, once an academic backwater, now enjoys important government and scholarly attention. U.S. government reports attribute Japan's competitive success in part to features of the Japanese system. ${ }^{1}$ Harvard Business School's major, multi-disciplinary study of American management's

1. See, e.g, REPORT OF THE SUBCOMM. ON FINANCIAL INSTITUTIONS SUPERVISION, REGULATION AND INSURANCE, TASK FORCE ON THE INTERNATIONAL COMPETITIVENESS OF U.S. FINANCLAL INSTITUTIONS OF THE HOUSE COMM. ON BANKING, FINANCE aND URBAN AFFaIRS, H.R. REP. No. 7, 101st Cong., 2d Sess. 7-8, 66, 189-90, 193-94 (1990) [hereinafter TASK FORCE REPORT] (Japanese "cross-shareholding arrangements create real linkages with real advantages"; “the 'keiretsu' system [is] a very effective system designed to maintain Japanese business competitiveness"). 
time horizons recommends, as a way to combat "short-termism" among U.S. managers, restructuring American corporate governance so that it resembles Japan's more closely. ${ }^{2}$

This newfound interest derives from two changes, one domestic and one international. The domestic change is evident in scholars' new understanding of America's corporate governance system; during a short period of time, the basic paradigm has shifted. The "traditional" model of American corporate governance presented the Berle-Means corporation-characterized by a separation of ownership and management resulting from the need of growing enterprises for capital and the specialization of management-as the pinnacle in the evolution of organizational forms. Given this model's dominance, the study of comparative corporate governance was peripheral; governance systems differing from the American paradigm were dismissed as mere intermediate steps on the path to perfection, or as evolutionary dead-ends, the neanderthals of corporate governance. Neither laggards nor dead-ends made compelling objects of study.

More recent scholarship challenges the "traditional" view, arguing that the separation of ownership and management-and the absence of substantial shareholders or lenders to monitor professional management-is historically and politically contingent. In particular, in the United States, populism, federalism, and interest group conflicts combined to restrict the growth of large financial intermediaries, especially banks, and constrained other efforts to oversee management, through a regulatory web of banking, insurance, tax, and securities laws. ${ }^{3}$ The American system may be the product of an evolutionary process, but its development has been affected by features of our politics, some of which are fundamental to democracy, some peculiar to American democracy. Nothing in that process assures the American system's productive superiority to systems that evolved under different conditions.

The second change-heightened international competition-has made it important to understand the contingency of American corporate governance. The globalization of commerce and the postwar reemergence of the Japanese and European economies has required American corporations to compete with organizations having dramatically different governance systems. In this new environment, competition exists not only among products, but also among governance systems, and American firms are not always winning. Thus, real world competition has obliged business scholarship to focus on comparative corporate governance. Because the American system is now seen as contingent,

2. Michael Porter, Remarks at the U.S. Securities and Exchange Commission Forum on Corporate Governance and American Economic Competitiveness: The Role of Shareholders, Directors and Management 41-62 (Mar. 20, 1992) (transcript on file with authors).

3. See Mark J. Roe, A Political Theory of American Corporate Finance, 91 CoLUM. L. REv. 10 (1991) [hereinafter Roe, A Political Theory]; Mark J. Rne, Political and Legal Restraints on Ownership and Control of Public Companies, 27 J. FIN. ECON. 7 (1990); Joseph A. Grundfest, Subordination of American Capital, 27 J. FIN. ECON. 89 (1990). See generally Michael C. Jensen, Eclipse of the Public Corporation, HARV. BUS. REV., Sept.Oct. 1989, at 61 . 
and other systems seemed in the 1980's to be doing better, understanding the differences has become urgent. ${ }^{4}$

Yet, we shall argue here, our system's characteristics color the lens through which the first comparative studies viewed the rest of the world. Analysis of American corporate governance has always sought to solve the problem of separation of ownership and control: who will monitor management in light of dispersed shareholdings. Favored candidates for this monitoring role have shifted from outside directors ${ }^{5}$ to the market for corporate control, and, most recently, to institutional investors. As a result, the primary focus in comparative studies of Japanese corporate governance has been the role of the main bank. Conventional wisdom among American scholars has been that the Japanese system solves the corporate governance problem-who monitors management-through continuous monitoring by a financial intermediary, rather than through intermittent and often disruptive monitoring by capital markets. ${ }^{6}$ Relying on this analysis, reform proposals have identified institutional investors as having the potential to provide Japanese-style monitoring in the American system. ${ }^{7}$

To date, comparative analyses of the Japanese corporate governance system have assumed that the central purpose of the Japanese system, like that of the American system, is solving the Berle-Means monitoring problem. We argue that the Japanese system serves a function in addition to the monitoring of management. Our Japanese model reflects not only the need for corporate governance, the traditional factor American scholars have identified as shaping corporate structures, but also the need to support production and exchange-what we will call contractual governance. ${ }^{8}$ To be sure, complex multi-level monitoring is part of the production process, but this monitoring is motivated not just by financial institutions seeking a return on capital, but also by product market competition. Bank monitoring thus should not be seen in isolation, but

4. Business Roundtable, Corporate Governance and American Competitiventess, 46 Bus. LAW. 241, 242-43 (1990); see sources cited supra notes 2-3.

5. See infra text accompanying notes 17-24.

6. See infra text accompanying notes 31-36.

7. See, e.g, Bernard S. Black, Agents Watching Agents: The Promise of Institurional Investor Voice, 39 UCLA L. REV. 811 (1992) [hereinafter Black, Agents Watching Agents]; Bernard S. Black, The Value of Institutional Investor Monitoring: The Empirical Evidence, 39 UCLA L. REV. 895 (1992) [hereinafter Black, Value of Institutional Investor Monitoring]; Ronald J. Gilson \& Reinier Kraakman, Reinventing the Outside Director: An Agenda for Institutional Investors, 43 STAN. L. REV. 863 (1991); Jensen, supra note 3.

8. While Carl Kester does not draw this distinction, his work, together with that of Professor Masahiko Aoki, is unusual in its focus on the relationship between the production process and corporate governance. See W. CARL KESTER, JAPANESE TAKEOVERS: THE GLOBAL CONTEST FOR CORPORATE CONTROL 53 (1991) [hereinafter KESTER, JAPANESE TAKEOVERS] ("The overall effect of Japanese corporate govemance is to foster tremendous efficiencies in the execution of business transactions by making it easier to build and maintain long-term relationships."); Masahiko Aoki, Toward an Economic Model of the Japanese Firm, 28 J. ECON. LITERATURE 1 (1990) [hereinafter Aoki, Toward an.Economic Model]; MASAHIKO AOKI, THE JAPANESE FIRM AS A SYSTEM OF ATTRIBUTES: A SURVEY AND RESEARCH AGENDA (Center for Economic Policy Research Working Paper No. 288, 1992) [hereinafter AOKI, A SYSTEM OF ATTRIBUTES]; W. CARL KESTER, GOVERNANCE, CONTRACTING, AND INVESTMENT TIME HORZONS (Harvard Business School Working Paper No. 92-003, 1991) [hereinafter KESTER, GoverNANCE]. 
as one specific (although important) kind of a wide range of contractual monitoring types in Japan. An empirical observation informs this perspective: although financial institutions hold one-half of Japanese public firm stock, often in highly-concentrated blocks, another quarter of Japanese stock is held by other corporations, often suppliers or customers.'

Our claims are modest. We do not contend that our model fully describes the Japanese system; we do not seek to displace the main-bank-as-monitor paradigm. Indeed, we doubt that any single model fully captures the system's complexity. Rather, we mean to show only that (1) our model captures an important element missed thus far, and that (2) intermediary monitoring is only one part of a larger Japanese system of contractual governance. We also do not seek to discredit proposals that would reform American corporate governance by enabling intermediaries to monitor management more effectively. The pathdependent development of the American Berle-Means corporation might well indicate that intermediary monitoring is now the best solution for the American corporation's deeper governance problems. But the broader contractual governance structure characteristic of large Japanese firms, having taken another evolutionary path, cannot be duplicated exactly in the United States by changing only the role of financial intermediaries. ${ }^{10}$

Apart from the corporate governance debate, international trade issues surround the keiretsu. Some Americans see keiretsu cross-ownership as an anticompetitive, exclusionary structure, sufficient to make it a subject of bilateral trade talks. ${ }^{11}$ Specifically, the U.S. Structural Impediments Initiative (SII) views cross-ownership as a productive, yet exclusionary, device.

These two functions of cross-ownership-monitoring and producing-are left unconnected in the literature. While we offer no comment on the specific elements of the SII (in fact, the keiretsu structure's efficiency may be a source of the exclusionary effects), academic theory would profit by seeing, as SII does, keiretsu cross-ownership not only as a managerial monitoring mechanism but as a productive structure as well. The bank-as-monitor theorists need to account for cross-ownership among nonfinancial producers. The impediments theorists must consider the potential organizational advantages arising from partial cross-ownership among factors of production. ${ }^{12}$

9. Stephen D. Prowse, The Structure of Corporate Ownership in Japan, 48 J. FIN. 1121, 1123 (1992); Yasaku Futatsugi, What Share Cross-Holdings Mean for Corporate Management, ECON. EYE, Spring 1990, at 17,18 .

10. See Mark J. Roe, Some Differences in Corporate Governance in Germany, Japan, and America, 102 YALE L.J. (forthcoming June 1993).

11. U.S. to Focus on "Keiretsu," Foreign Investment in SI, KYODO NEwS SERV., July 27, 1992 (reporting U.S. Treasury Dept. pressure on Japan to force keiretsu to become more "transparent" during bilateral Structural Impediments Initiative talks), available in LEXIS, Nexis Library, Kyodo News Service File; see also PAUL SHEARD, KEIRETSU AND ClOSEDNESS OF THE JAPANESE MARKET: AN ECONOMIC APPRAISAL (Institute of Social and Economic Research, Osaka University Discussion Paper No. 273, 1992) (economic analysis of claim that keiretsu is exclusionary).

12. We are quite conscious that our theory here parallels antitrust developments in the 1960's and 1970's. 
In Part I, we sketch the development of the traditional Berle-Means conception of American corporate governance and the succession of potential monitors that have led to a comparative focus on Japan. In Part II, we briefly summarize the dominant theme of current comparative analysis of Japanese corporate governance: the monitoring role of the main bank. In Part III, we set out our contractual governance model of the Japanese corporate system, and, in Part IV, we explore the model's implications both for comparative corporate governance analysis of the Japanese system and for reforming America's corporate governance system.

\section{THE Berle-Means Model of AMERICAN CoRporate GovernanCE}

In 1932, Adolf Berle and Gardiner Means announced the separation of ownership and control in American industry. The Modern Corporation and Private Property, ${ }^{13}$ a book that for some sixty years has defined the intellectual mission of American corporate governance, reported that owners of major corporations had become atomistic shareholders lacking the ability, skill, information, and often the incentives to monitor the performance of specialized managers. ${ }^{14}$ Thereafter, the corporate governance debate became a search for the organizational Holy Grail: a mechanism to bridge the separation of ownership and control by holding managers accountable for their performance.

The modern corporate governance literature has treated this separation as the efficient response to economic forces. Specialization of risk bearing increased the availability of capital by opening investment to individuals who would not be active in the firm's operations, and reduced the cost of capital by allowing diversification. ${ }^{15}$ Efficiency became the standard in the corporate governance debate. To increase the value of the corporation, control is delegated to managers with specialized skills. But this delegation also gives managers the discretion to advance their own agenda at the shareholders' expense. The purpose of corporate governance, thus, became minimizing the sum of the costs involved in aligning managers and shareholders' incentives and in unavoidable selfinterested managerial behavior. ${ }^{16}$

During that period, the U.S. government attacked partial vertical integration-not unlike that of the keiretsu - on the assumption that, absent clearly efficient motives and effects, the structures must have been exclusionary. Theorists, and finally courts, later came to view many of these structures as more efficient than exclusionary. See Roe, supra note 10. (1933).

13. AdOLF A. BERLE, JR. \& GARDINER C. MEANS, The MOdern CORPORATION AND PRIVATE PROPERTY

14. Id. at $47-68$.

15. Alfred Chandler argues that the increasing complexity of business was a more important cause of separation than the dispersion of stock holdings. ALFRED D. CHANDLER, JR., SCALE AND SCOPE: THE DYNAMICS OF INDUSTRIAL CAPITALISM 232 (1990). Existing owners lacked the skills and information necessary either to run modern corporations themselves or to monitor the decisions of those who did. Id.

16. See Michael C. Jensen \& William H. Meckling, Theory of the Firm: Managerial Behavior, Agency Costs and Ownership Structure, 3 J. FN. ECON. 305 (1976). 
The most enduring institution for minimizing agency cost has been the independent director. The concept-that shareholders would bridge their separation from managers by electing nonemployee directors to monitor management performance-has reached the status of conventional wisdom. The Business Roundtable, ${ }^{17}$ the Conference Board ${ }^{18}$ the American Bar Association, ${ }^{19}$ the American Law Institute, ${ }^{20}$ and the Delaware courts ${ }^{21}$ have all come to accord independent directors the primary monitoring role. Substantial doubt remains, however, as to independent directors' effectiveness. They typically are chosen by management and perceive themselves as "serving at the pleasure of the CEO-Chairman." 22 In addition, most are chief executive officers of other large companies ${ }^{23}$ who are unlikely to monitor more energetically than they would want to be monitored by their own boards. ${ }^{24}$

Hostile takeovers during the late 1970's and 1980's provided another technique for minimizing agency costs. Here the external monitor-the market-replaced the internal monitor. When the market price of a company's stock signalled poor managerial performance, those who thought they could do better paid the shareholders a premium-reflecting some sharing of the potential gain-for the privilege of improving the target company's performance. But owing in no small part to the discretion that the Delaware courts and other states' legislatures gave target management, takeovers grew more expensive, and some states made many takeovers too costly to attempt. ${ }^{25}$ Moreover, takeovers were reactive at best: they attacked much bad management but did not directly prevent it. Finally, at least the 1980's generation of takeovers depended on debt financing, which dried up at the beginning of the 1990's. Many such takeovers

17. See Business Roundtable, supra note 4, at 247-48; Business Roundtable, The Role and Composition of the Board of Directors of the Large Publicly Owned Corporation, 33 Bus. LAW. 2083, 2108 (1978) ("We note the strong tendency of U.S. business corporations to move toward a board structure based on a majority of outside directors-and we endorse it.").

18. See JEREMY BACON \& JAMES K. BROWN, THE CONFERENCE BOARD, CORPORATE DIRECTORSHIP PRACTICES: ROLE, SELECTION AND LEGAL STATUS OF THE BOARD (1975).

19. See Committee on Corporate Laws, Section of Corporation, Banking \& Business Law, American Bar Association, Corporate Director's Guidebook, 33 Bus. LAW. 1595, 1619-21 (1978).

20. See AMERICAN LAW INSTITUTE, PRINCIPLES of CoRporate GovernaNCE: ANALYSIS AND RECOMMENDATIONS § 3A.01 (Proposed Final Draft 1992).

21. The Delaware courts have assigned special weight to outside directors' decisions. See Weinberger v. UOP, Inc., 457 A.2d 701 (Del. 1983) (finding merger failed fairness test where feasibility study not shown to outside directors); Zapata Corp. v. Maldonado, 430 A.2d 779 (Del. 1981) (dismissing derivative suits where self-interested board members delegated litigation decision to independent committee of disinterested board members); William T. Allen, Independent Directors In MBO Transactions: Are They Fact or Fantasy?, 45 BUS. LAW. 2055 (1990) (arguing that special committees of outside directors may, if used properly, protect shareholder interests) (Allen is Chancellor of the Delaware Court of Chancery).

22. JAY W. LORSCH, PAWNS OR POTENTATES: THE REALITY OF AMERICA'S CORPORATE BOARDS 17 (1989).

23. Id. at 18 ( $63 \%$ of outside directors are CEO's of other companies).

24. See generally Gilson \& Kraakman, supra note 7, at 872-76 (analyzing failings of outside director concept).

25. See Mark J. Roe, Takeover Politics, in THE DEAL DECADE (Margaret Blair ed., forthcoming 1993). 
have resulted in costly recapitalizations, often in Chapter 11. By 1992, the market for corporate control was quiet.

The takeover market's decline coincided with a realization among commentators that perhaps the premise underlying the Berle and Means analysis no longer held. While no one was looking, shareholders had reaggregated somewhat; institutional investors held half the stock of the largest American corporations, although in small blocks. ${ }^{26}$ The blocks were never as concentrated as those now found in Japan, but the number of players was often sufficiently small so that concerted investor action could be considered—or at least prescribed by academics. While a takeover's governance benefits rested on an outsider buying enough stock to become a large stockholder, the new aggregation raised the possibility that existing large stockholders could provide those benefits without takeovers. Some institutions-usually public pension funds-began to act somewhat like monitors, making proposals concerning takeover defenses, shareholder advisory committees, and director independence. ${ }^{27}$ Emboldened by this activity, reformers even suggested that institutional investors had the power to make the outside director concept viable, ${ }^{28}$ or to set forth the changes necessary to make it viable. ${ }^{29}$

Once it became clear (1) that the Berle-Means corporation was historically and politically contingent and (2) that intermediaries could play a role, other patterns of corporate governance became plausible alternatives, including foreign patterns in which intermediaries have long played a more important role than they have played in the United States. ${ }^{30}$ Foreign structures no longer seem to be laggards struggling to catch up to America's advanced capital markets; instead, they have become alternatives to our own structures. Even if we would never use the foreign structures as a blueprint for American reform, they might help us chart a new course for the large American public corporation.

26. Carolyn Kay Brancato, The Pivotal Role of Institutional Investors in Capital Markets, in INSTITUTIONAL INVESTING: THE CHALLENGES AND RESPONSIBILITIES OF THE 21ST CENTURY 3, 21, Table 1-7 (Amold W. Sametz ed., 1991); Carolyn Kay Brancato, Institutional Investors and Capital Markets: 1991 Update 18 (1991) (unpublished manuscript, on file with authors).

27. See Gilson \& Kraakman, stupra note 7, at 867-76 (reviewing strategies).

28. See id.; see also Ronald J. Gilson, Lilli A. Gordon \& John Pound, How the Proxy Rules Discourage Constructive Engagement: Regulatory Barriers to Electing a Minority of Directors, 17 J. CORP. L. 29, 30-34 (1992).

29. See, e.g., Bernard S. Black, Shareholder Passivity Reexamined, 89 MrCH. L. REv. 520 (1990) (reviewing regulatory barriers to institutional shareholders actively participating in corporate governance); John C. Coffee, Jr., Liquidity Versus Control: The Institutional Investor as Corporate Monitor, 91 CoLuM. L. REV. 1277 (1991) (asserting those seeking influence should forego liquidity). As Louis Lowenstein points out, index funds, with tiny management fees of two basis points, lack the resources to monitor. Louls LOWENSTEIN, SENSE AND NONSENSE IN CORPORATE FINANCE 220 (1991). They are the ultimate Berle-Means free riders, capable of acting but depending on others to monitor for them.

30. This argument parallels a similar one made by Michael Piore and Charles Sabel that the American system of industrial organization is historically and politically contingent. MICHAEL J. PIORE \& CHARLES F. SABEL, THE SECOND INDUSTRIAL DIVIDE: POSSIBILITIES FOR PROSPERITY 19-48 (1984). The parallel is especially interesting in light of our suggestion that the Japanese system can be understood as one of industrial organization as much as corporate governance. See infra Part III. 


\section{The JAPANESE MAIN BANK AS THE MISSING MONITOR}

Japan, it appeared, had developed a solution to the Berle-Means monitoring problem: the main bank. A Japanese corporation had a single bank that provided the largest share of its borrowings and also held a substantial equity position. ${ }^{31}$ Moreover, the main bank spoke with more than its own authority. Each main bank seemed to act as the delegated monitor for other banks lending to its client corporation, so that, in effect, the creditors spoke with a single voice. ${ }^{32}$ The main bank required review of a client corporation's business plans ${ }^{33}$ and, in the event of poor performance, intervened to impose new management or strategies. It often bailed out a troubled company. ${ }^{34}$ Thus, the main bank was said to provide "an important substitute mechanism for what in effect is a 'missing' takeover market in Japan; or to put it somewhat differently the main bank system serves to internalize the market for corporate control."35

It is hardly surprising that American commentators were drawn to this picture of a monitoring paragon; ${ }^{36}$ the Japanese main bank confirmed the historical and political contingency of American arrangements. American political history prevented American financial intermediaries from directly monitoring management. ${ }^{37}$ America never had widespread main banks, but where financial intermediaries were not so severely limited, as in Japan, they helped bridge the separation of ownership and management.

31. See, e.g., Paul Sheard, The Main Bank System and Corporate Monitoring and Control in Japan, 11 J. ECON. BEHAV. \& ORG. 399 (1989). Sheard reports that for corporations listed on the Tokyo Stock Exchange, the main bank was the largest or second largest shareholder in $39 \%$ of the cases in his sample and among the top five shareholders in $72 \%$ of the cases. $I d$. at 402 . Similarly, a recent study reports that a Japanese corporation's largest lender owned on average $6.2 \%$ of equity, its five largest lenders owned on average $18.2 \%$ of equity, and in 57 of the 133 sample corporations, the largest lender was the largest shareholder. Stephen D. Prowse, Institutional Investment Patterns and Corporate Financial Behavior in the Unired States and Japan, 27 J. FN. ECON. 43, 46-47 (1990).

32. See Sheard, supra note 31, at 401-03; PAUL SHEARD, DELEGATED MONITORING AMONG DELEGATED MONITORS: PRINCIPAL-AGENT ASPECTS OF THE JAPANESE MAIN BANK SYSTEM (Australian National University and Osaka University Working Paper, 1992). Such a cooperative allocation of monitoring responsibility minimizes duplication and, because other banks act as first-line monitors with respect to other companies, reduces incentives to free ride.

33. "In a 'good' main bank relationship, the firm will consult the bank closely when drawing up its business plans and will provide regular reports on its performance." Sheard, supra note 31, at 403.

34. See, e.g., Takeo Hoshi, Anil Kashyap \& David Scharfstein, The Role of Banks in Reducing the Costs of Financial Distress in Japan, 27 J. FN. ECON. 67 (1990). For descriptions of active main bank intervention in crises, see KESTER, JAPANESE TAKEOVERS, supra note 8, at 70-73; Paul Sheard, The Economics of Interlocking Shareholding in Japan, 45 RICERCHE ECONOMICHE 421, 436-38 (1991).

35. Sheard, supra note 31 , at 407.

36. For example, Michael Jensen stressed that "LBO partnerships play a dual funding and oversight role that is similar in many ways to that of the main banks in the Japanese keiretsu." Michael C. Jensen, Corporate Control and the Politics of Finance, J. APPLIED CORP. FIN., Summer 1991, at 13, 22. Gilson and Kraakman stated the corporate governance challenge as designing "a new structure that duplicates the monitoring capabilities of the LBO and [Japanese] banker models." Gilson \& Kraakman, supra note 7, at 879. We return to Jensen's comparative analysis of the LBO association later. See infra text accompanying notes $109-118$.

37. See Roe, A Political Theory, supra note 3. 
The standard Japanese bank monitoring story needs qualifications in two respects. To the extent that a monopoly control of credit in the Japanese banks was critical to their power, the rise of alternative credit sources and the growth of corporate retained earnings diminished it. ${ }^{38}$ While banks-which remain as stockholders-might still intervene in the event of a crisis, ${ }^{39}$ and large blocks, even if normally passive, might motivate managers to avoid a crisis, crisis intervention is a more limited role than that of an ongoing monitor of business strategy. The primary active role of the banks' large stockholdings would not be to improve normal corporate governance before crisis-the primary American goal-but to facilitate financial and managerial restructuring when big problems arose-an important but secondary American goal.

Second, characterizations of the main bank as "internaliz[ing] the market for corporate control ${ }^{\$ 40}$ need clarification. Displacing inefficient management-management that is performing so poorly as to threaten the corporation's economic viability-is one function of takeovers. But it is neither the only function ${ }^{41}$ nor, over lengthy periods, necessarily the most important one. During the 1980 's, the dominant acquisition motive appears not to have been to remove management whose operational performance threatened to bankrupt the company,

38. Kester tells us:

Financial managers at manufacturing companies generally concur with this description of the [lessening] degree of monitoring and control exerted over their companies by their traditional main banks. Whereas all but one of the companies in the field sample indicated that their corporate plans and investments were closely examined by banks during the 1950-1980 period, none reported being subject to such scrutiny today. Although meetings with lenders are still held semi-annually or at least annually to discuss performance, these have apparently evolved into largely perfunctory presentations of past performance rather than substantive discussions of future capital investment.

KESTER, JAPANESE TAKEOVERS, supra note 8, at 197. Other commentators offer similar observations. See, e.g., JAMES C. ABEgGLen \& GEORGE STALK, JR., KAISHA, THE JAPANESE CORPORATION 189 (1985) ("The conclusion is that dependence on a bank is no more to the liking of Japanese management than management in other countries, and for leading Japanese companies no longer a significant issue."); J. Mark Ramseyer, Legal Rules in Repeated Deals: Banking in the Shadow of Defection in Japan, 20 J. LEG. STUD. 91, 98 (1991). Available data show a decreased role for banks. In the early 1970's, listed Japanese companies generated internally only $36 \%$ of their net increase in funds; by the early 1980's, internally generated funds accounted for $71 \%$ of the increase. The data with respect to bank borrowings are consistent. In the early 1970 's, $41 \%$ of the net increase in funds came from bank borrowings. By the mid-1980's, the bank share had dropped to 6\%. Paul Sheard, Japanese Corporate Finance and Behaviour: Recent Developments and the Impact of Deregulation, in JAPANESE FINANCIAL MARKETS AND THE ROLE OF THE YEN 55, 56 (Colin McKenzie \& Michael Stutchbery eds., 1992). A slowing Japanese economy may well lead industrial firms short of cash to restore main bank relationships.

39. Professor Aoki states: "In the normal course of events ... the main bank exercises explicit control neither in the selection of management nor in corporate policy making." Aoki, Toward an Economic Model, supra note 8, at 14 (emphasis added). "Financial control by bank cum stockholders concerning corporate direction is exercised only in a business crisis." $I d$. at 16.

40. Sheard, supra note 31 , at 407.

41. For efforts to identify what proportion of hostile takenvers are made to displace inefficient management as opposed to synergy or other strategies, see, e.g., Kenneth Martin \& John McConnell, Corporate Performance, Corporate Takeovers, and Management Turnover, 46 J. FiN. 671 (1991); Randall Morck, Andrei Shleifer \& Robert W. Vishny, Alterative Mechanisms for Corporate Control, 79 AM. ECON. REV. 842 (1989); Randall Morck, Andrei Shleifer \& Robert W. Vishny, Characteristics of Targets of Hostile and Friendly Takeovers, in CORPORATE TAKEOVERS: CAUSES AND CONSEQUENCES 101 (Alan J. Auerbach ed., 1988); see also RONALD J. GILSON \& BERNARD S. BLACK, THE LAW AND FINANCE OF CORPORATE ACQUISTIONS: 1991 SUPP. 37-86 (1991) (summarizing literature). 
but instead to dismantle ineffective conglomerates that were in danger only of continuing to throw away their free cash flow. ${ }^{42}$ Managers were inefficient in using an unwieldy structure, but once the (bad) decision had been made to keep the structure and invest free cash flow in it, they did as good a job as could be done. The prototypical target was RJR Nabisco, not Chrysler. If the Japanese main bank has served thus far primarily as a crisis manager, allocator of capital, and gatekeeper to bankruptcy, it has not yet shown itself to be a complete substitute for America's 1980's takeovers. A complete monitor must (at least) reduce poor use of free cash flow, a problem Japan is only beginning to face. True, the existence of large blocks of stock whose holders are inactive (short of crisis) could improve senior managers' incentives and motivation. The banks, with large blocks of stock and (sometimes still) large debt, could define a crisis as requiring intervention before there is as much organizational decline as would induce a Chapter 11 proceeding. Even the new reduced role of the main bank might provide a useful model.

Moreover, our point is not to criticize the limits of the Japanese main bank system. Indeed, the very limits are said by Professors Aoki and Sheard to be central to the system's genius. The limits allow managers freedom from outside pressure except in crisis so that they can respect commitments to employees. In times of crisis, the main bank provides a safety net-the funds and expertise to bail the employees out-although at some personal cost to the employees and with some positive probability of liquidation. Avoiding bank intervention gives both management and employees an incentive for team performance. ${ }^{43}$

Our point is instead that the Japanese corporate governance system is not only about Berle-Means corporate governance. It also may be an effort to link the structural features of the corporation directly to the efficiency of the corporation's actual production; it is about industrial organization, not just corporate governance. Viewing the Japanese system through Berle-Means blinders, in the belief that it reflects only an effort to bridge the separation of ownership and control, will cause us to misunderstand it and, as a result, to miss the lessons that comparative analysis can offer.

Recent work by economists is consistent with a model of Japanese contractual governance. Much of it has focused on the Japanese firms' ability to provide incentives making the interests of owners and employees compatible

42. See Sanjai Bhagat, Andrei Shleifer \& Robert W. Vishny, Hostile Takeovers in the 1980s: The Return to Corporate Specialization, in BROORINGS PAPERS ON ECONOMIC ACTIVITY: MICROECONOMICS 1 (Martin N. Baily \& Clifford Winston eds., 1990); Amar Bhide, The Causes and Consequences of Hostile Takeovers, J. APPLIED CORP. FIN., Summer 1989, at 36, 52 ('real source of gains in hostile takeovers lies in splitting up diversified companies"); Randall Morck, Andrei Shleifer \& Robert W. Vishny, Do Managerial Objectives Drive Bad Acquisitions?, 45 J. FIN. 31, 47 (1990) (evidence "that the source of bust-up gains in the 1980s is the reversal of the unrelated diversification of the 1960 s and the 1970 ").

43. See Aoki, Toward an Economic Model, supra note 8, at 14-15; Masahiko Aoki, Ex Post Monitoring by the Main Bank (1992) (unpublished manuscript, on file with authors) [hereinafter Aoki, Ex Post Monitoringl; Masahiko Aoki \& Paul Sheard. The Role of the Japanese Main Bank in the Corporate Governance Structure in Japan (1991) (unpublished manuscript, on file with authors). 
and on enforcing implicit contracts among related firms. ${ }^{44}$ In the next Part, we seek to extend this work by explaining the keiretsu as a form of industrial organization motivated by the need to support multilateral relation-specific investment. Then we explore the circumstances, notably competition in the product market, under which such an organization can flourish.

\section{The Japanese System as Global Contractual Governance OF WHICH SPECIFIC CORPORATE GOVERNANCE IS A SUBSET}

One-third of Japanese corporate cross-holdings is not held by financial institutions, but by industrial companies, which are often suppliers or customers of the portfolio company. ${ }^{45}$ What is the function of this one-third of the cross-holdings? Can the Japanese system be partly understood as a form of industrial organization, as a means to integrate customers and suppliers, different pieces in the production process, of which capital suppliers are only one component? In this Part, we develop a simple model of the Japanese system in which cross-ownership's primary purpose is to foster efficient production, not directly to provide monitoring by the residual equity holder. The inquiry here focuses less on corporate governance than on industrial organization. ${ }^{46}$

Two introductory points should be made, one substantive and one methodological. The substantive point is that we take as the Japanese structure not a single Japanese corporation in isolation, but the keiretsu structure-the interlocking webs of firms, which loom so large in the Japanese economy. ${ }^{47}$

44. Professor Aoki may be the most explicit in identifying these links. Concentrating on the structure of a single corporation, his three Duality principles-between a firm's coordination and incentive modes, its decision hierarchy and incentive-ranking hierarchy, and the interests of ownership and employees-link the Japanese corporation's success to a particular economic environment and a particular type of production. AOKI, A SYSTEM OF ATTRIBUTES, supra note 8, at 10-20. See KESTER, JAPANESE TAKEOVERS, supra note 8, at 53-82 (treating, most ambitiously, overall structure of keiretsu as designed to support exchange among member corporations, as system of contractual, not corporate, governance); KESTER, GovERNANCE, supra note 8, at 14-31 (same); GERALD T. GARVEY \& PETER L. SWAN, THE INTERACTION BETWEEN FINANCIAL AND EMPLOYMENT CONTRACTS: A FORMAL MODEL OF JAPANESE CORPORATE GOVERNANCE (Australian Graduate School of Management, University of New South Wales Working Paper, 1991) (linking main bank and keiretsu cross-holding features of Japanese system to structure of employee incentives); PAUL SHEARD, THE ECONOMICS OF INTERLOCKING SHAREHOLDINGS IN JAPAN 21-22 (Center for Economic Policy Research, Stanford University Working Paper No. 259, 1991); Erik Berglof \& Enrico Perotti, The Japanese Keiretsu as a Collective Enforcement Mechanism (Jan. 1989) (unpublished manuscript, on file with authors) (modeling keiretsu as technique for enforcement of implicit contracts among member firms).

45. Futatsugi, supra note 9 , at 17,18 .

46. Traditional theory of the firm was not a theory of the firm at all, but rather described how firms behaved under different competitive conditions. See, e.g., R.H. Coase, The Nature of the Firm, 4 ECONOMICA 386 (1937); R.H. Coase, The Institutional Structure of Production, 82 AM. ECON. REV. 713 (1992) (Nobel lecture). The firm itself remained a black box. An agency-based theory of the firm opened the box to find a nexus of contracts. More recent comparative corporate governance scholarship seeks to move the analysis down yet another level and examine how firm structure-the particular pattern of contracts whose nexus is the firm-relates to the actual productive activities of the firm. Like the early physicists, we are finding boxes within boxes.

47. While only one-tenth of $1 \%$ of Japanese corporations belong to a keiretsu, member firms account for approximately one-quarter of total corporate sales and represent one-half of all listed Japanese corporations. KESTER, JAPANESE TAKEOVERS, supra note 8, at 55. 
The study of American corporate governance concentrates on the structure of a single firm, say, General Motors; a Japanese keiretsu may include the equivalent of GM, GE, US Steel (now USX), and IBM, as separate firms. A keiretsu might have a car assembler, a steel company (which supplies steel sheets for cars and buys furnaces for its factories from the electrical machinery company), and a computer firm (which supplies microprocessors for the cars, appliances, machines, and factory).$^{48}$ Each company would have some separate existence, but through extensive cross-ownership, ${ }^{49}$ these quasi-firms would blend at the edges. We take the entire structure-all these quasi-firms, in Japan, the keiretsu-as the meta-firm, the object of our study. ${ }^{50}$ In the United States, we would typically view these as separate firms that interconnect only via contract. Americans would define the "firm" as including only the wholly-owned subsidiaries of the core firm; GM's Fisher body plant and EDS's computer operation-once separate companies-would now be seen as part of a single, GM firm.

Although about $50 \%$ of the stock in large Japanese firms is held by banks and insurers, often in large blocks, other corporations own about $25 \%$ of the large-firm stock. Often these other firms have supplier-customer relations. ${ }^{51}$ Banks and insurers are not the only large block stockholders: steelmakers, for example, own blocks of the leading automakers, their customers. ${ }^{52}$ This is our point of departure: although we do not need to displace the bank monitoring theories, focusing on bank monitoring alone could blind us to a potentially critical feature of the Japanese ownership structure. We hypothesize that fostering relational contracting is the function of the one-third of corporate cross-ownership not held by the banks.

48. Japanese keiretsu are of two general types, vertical and horizontal (or intermarket). Vertical keiretsu comprise suppliers, distributors and capital providers of an industry-specific manufacturing concem. In contrast, horizontal keiretsu include a number of manufacturers across different industries, a trading company, a large bank, and insurance companies. Some vertical keiretsu overlap with horizontal keiretsu. See Michael Gerlach, Alliance Capitalism: The Social Organization of Japanese Business 12-13 (1992) (unpublished manuscript, on file with authors); Ulrike Schaede, Corporate Governance in Japan: Institutional Investors, Management Monitoring and Corporate Stakeholders (Aug. 1992) (unpublished manuscript, on file with authors) (developing typology for distinguishing between the two forms of groups).

49. To be sure, two-thirds of the cross-ownership would be held by financial institutions, but because the financial institutions are partly owned (although at a lower level) by industrial companies, we could exaggerate and make the financial institution transparent as a gateway for industrial cross-ownership.

50. In so doing we pass over a core problem in the theory of the firm: defining the object of inquiry. One might conceive of a theory of the firm as encompassing three questions: 1) what is the firm, that is, how do we define the boundary between market and hierarchy?; 2) what is the efficient boundary of the firm, that is, given that we know a firm when we see one, what activities should be undertaken within it?; and 3) how are decisions made and monitored within the firm?, that is, the traditional corporate governance problem. It is interesting to note that although the second and third questions plainly depend on the answer to the first, the vertical integration and corporate governance literatures-responses to the second and third questions-are far more developed than efforts to understand the first. For example, is Silicon Valley a firm? In this Article, we assume the answer to the first question: the firm relevant to our inquiry is the keiretsu.

51. Futatsugi, supra note 9, at 17.

52. Id. at 18 . 
We offer only a model, not a rich, institutional description of the various keiretsu structures. As with any model, ours carries with it familiar limitations: to highlight the importance and operation of a complex system, we must necessarily make simplifying assumptions.

\section{A. A Stylized Model of the Japanese System}

\section{The Continuum: Contract Versus Organization}

Imagine factors of production for a product-say, five parties consisting of a distributor, two parts suppliers, a bank, and an assembler-which sit down to negotiate a cooperative structure for producing the good. ${ }^{53}$ Efficient production requires all the parties to make substantial investments in relationspecific capital. Labor at the assembly firm must learn flexible production methods and skills peculiar to this enterprise and its team of coworkers. ${ }^{54}$ The suppliers have to locate their production close to the assembler. They must develop, with the assembler, design and quality standards and procedures and a just-in-time delivery system, all specific to the parties and the product. The assembler, in tum, must invest jointly with the parts suppliers in the development of standards and procedures and, in turn, must specialize its assembly facilities . for the suppliers' parts. Finally, the supplier of capital assures that short-term swings in the business cycle do not leave the venture short of funds, insuring against the business cycle for those who cannot diversify their relation-specific investments. ${ }^{55}$ But the benefits of relation-specific investment come with a cost: once a factor so invests, the other factors could appropriate the gains from cooperation. The industrial organization challenge, then, is to design a structure that provides the parties incentives to make the optimal investment in relationspecific assets. Efficiency requires loose, long-term, relational investments, which create the risk of opportunism. Maximizing productive efficiency and minimizing opportunism are the goals of contractual governance.

But what type of arrangement will maximize efficiency and minimize opportunism? The continuum of possible structures is anchored by two extremes, one pure contract, the other pure organization. On the idealized contractual end of the continuum, one factor becomes the entrepreneur and uses highly specific contracts to organize production; these contracts specify the terms on which the entrepreneur can acquire goods and services from the other factors under

53. Our stylized model most closely resembles a vertical keiretsu. There are, however, substantial intrakeiretsu purchases and sales even within an intermarket, horizontal keiretsu. See infra note 70.

54. See AOKI, A SYSTEM OF ATTRIBUTES, supra note 8, at 8; HDESHI ITOH, JAPANESE HUMAN RESOURCE MANAGEMENT FROM THE VIEWPONT OF INCENTIVE THEORY (Center for Economic Policy Research, Stanford University Working Paper No. 258, 1991) (reviewing economic structure of Japanese employment pattems); SHEARD, supra note 44, at 24-26.

55. See, e.g., SHEARD, supra note 44 , at 21-24. 
all possible future circumstances, thereby preventing all involved from acting opportunistically. Every contingency is anticipated and dealt with in this perfect contract, whose terms will be judicially enforced without significant friction. ${ }^{56}$ This "firm" is a loose connection of factors that are linked through a nexus of arm's-length contracts. On the idealized organizational end of the continuum, few arm's-length contracts are specified: the entrepreneurial factor buys up, or establishes by itself, the other factors. This firm vertically integrates. ${ }^{57}$

These two idealized extremes capture much of the tension that has motivated American academic debate over contractual governance. Limited foresight and the threat opportunism presents to relation-specific investment render neoclassical contracting incapable of providing a complete structure for organizing production. Perfect contractual governance is impossible. But the other extreme, vertical integration, presents its own problems. Organizing production solely within a firm increases the capital and managerial expertise required and creates the BerleMeans problem. The substitution of ownership for market procurement-making rather than buying - requires effective internal incentives and monitoring to avoid organizational opportunism.

\section{Japan: A Hybrid Between Contract and Organization}

Our model puts the Japanese keiretsu in the middle of the continuum, a region that has received inadequate attention in the American corporate governance debate. ${ }^{58}$ Partial vertical integration through partial cross-ownership, combined with market contracting, incorporates features of both contract and organization. ${ }^{59}$

Suppose our factors of production seek to avoid both the bounded rationality that limits neoclassical contracting and the agency costs that limit corporate governance. They deliberately use an open-ended relational contract-one committing the parties to a long-term affiliation for the production of the good, but consigning to the parties' good intentions the way in which the terms of trade for relation-specific assets will respond to unexpected changes in conditions. Kester, for example, describes the basic agreement between supplier

56. See Oliver E. Williamson, The Economic Institutions of CaptTalism 69 (1985).

57. See Oliver D. Hart, Incomplete Contracts and the Theory of the Firm, 4 J.L. ECON. \& ORG. 119, 120 (1988); Benjamin Klein, Robert G. Crawford \& Armen A. Alchian, Vertical Integration, Appropriable Rents, and the Competitive Contracting Process, 21 J.L. \& ECON. 297 (1978).

58. The lack of attention to intermediate forms of organization in the United States may reflect the character of production during the debate. As Piore and Sabel show, the pattern of U.S. manufacturing prior to 1980 stressed specialized machinery and unspecialized labor as a means of creating and exhausting scale economies in a period of relative economic calm. PIORE \& SABEL, supra note 30 , at 27 . Intermediate solutions work well where greater numbers of products produced, and lower product life-spans, increase retums from flexible human-capital investment yet decrease economies of scale resulting from specialized machinery. See Aoki, Toward an Economic Model, supra note 8, at 7-10.

59. On this point, our strongest precursor is Kester. KESTER, JAPANESE TAKEOVERS, supra note 8, at 80-81. Some of what seem to American eyes to be corporate governance matters are really corporate arrangements that facilitate relational contracting. 
and assembler in the Japanese auto industry: "The buyer and seller will operate on a basis of mutual respect for each other's autonomy and undertake to establish and maintain an atmosphere of mutual trust in business dealings.

While this intermediate solution has the surface appeal of steering a course between the Scylla of neoclassical contracting and the Charybdis of vertical integration, without more, the covenant of future good faith is illusory. What assures the factor providers that one of them will not take advantage of the others tomorrow when exploitation is possible? In the absence of an effective barrier to opportunism, the corrosive effect of anticipated misbehavior will cause midrange solutions to devolve into either vertical integration or short-term contracting. ${ }^{61}$

Cross-ownership of equity among factor providers-a central feature of the Japanese system-helps reduce this opportunism. ${ }^{62}$ Suppose that in our hypothetical organizational design problem, each of the five factor providers supports its investment in relation-specific assets by exchanging equity interests so that each owns twenty percent of the other four. ${ }^{63}$ In this setting, the crossholdings help enforce the commitment to a good faith determination of new terms of trade for relation-specific assets following the occurrence of an unexpected state of the world. Cross-ownership prevents the party having the chance to act opportunistically from doing so. ${ }^{64}$ With stock ownership, the other

60. KESTER, GOVERNANCE, supra note 8, at 19. This mode of contracting is not limited to the automobile industry. Kester refers more generally to claims "that a typical Japanese contract does not even state definitely the transactions at stake so as not to restrict the flexibility considered necessary for good performance." Id. at 19 n.7. Similarly, Akio Morita, chairman of Sony, explains that all Japanese contracts contain a provision to the effect that "in the event of disagreement, both parties to the contract agree[] to sit down together in good faith and work out their differences." Akio Morita, Do Companies Need Lawyers? Sony's Experiences in the United States, 30 JAPAN Q. 2, 3 (1983).

61. Note how closely the description of Japanese contracting parallels Oliver Williamson's description of the simple form of contract that would suffice in a world in which opportunism was somehow impossible: "A general clause, to which both parties would agree, to the effect that 'I will behave responsibly rather than seek individual advantage when an occasion to adapt arises'..." Oliver E. Williamson, Transaction-Cost Economics: The Governance of Contractual Relations, 22 J.L. \& EcON. 233, 241 (1979). See generally Anthony T. Kronman, Contract Law and the State of Nature, 1 J.L. ECON. \& ORG. 5 (1985). For an effort to understand barriers to opportunism in dealings between Japanese firms, see Ronald J. Gilson, Value Creation by Business Lawyers: Legal Skills and Asset Pricing, 94 YALE L.J. 239, 308-10 (1984).

62. This protection is a hybrid of spontaneous and intentional governance techniques, that is, invisible hand techniques as well as a conscious contractual protective govemance structure. See Oliver Williamson, Economic Institutions: Spontaneous and Intentional Governance, 7 J.L. ECON. \& ORG. 159 (1991) (Special Issue). The literature also contains models of spontaneous techniques falling on both the nenclassical contracting and organizational ends of the continuum. See Drew Fudenberg, Bengt Holmstrom \& Paul Milgrom, Short-Term Contracts and Long-Term Agency Relationships, 51 J. ECON. THEORY 1 (1990) (succession of short-term contracts is equivalent of first-best long-term contract); David Kreps, Corporate Culture and Economic Theory, in PERSPECTIVES ON POSITIVE POLITCAL ECONOMY 90-143 (James E. Alt \& Kenneth A. Shepsle eds., 1990) (corporate reputation model). We do not consider these models here.

63. We recognize that (1) Japanese cross-ownership rarely rises above $5 \%$; (2) the keiretsu groupings have more than five members; and (3) there are public stockholders. We use five members and $20 \%$ to simplify the model, not to describe the typical cross-ownership in Japan.

64. One also might formulate the arrangement as a means of enforcing an ex ante risk sharing agreement, in effect assuring that any good fortune is shared among the participants. See SHEARD, supra note 44, at 13-14. 
factors could coalesce to replace the opportunistic factor provider's managers, or threaten to sell the stock, which would leave the recalcitrant managers without "protection" from market havoc (or even a takeover). ${ }^{65}$ So long as partners making a relation-specific investment do not expect any one party systematically to be advantaged over time - that is, the expectation of states favoring a factor is random-cross-holdings of equity help to support long-term productive exchange, reducing the opportunism of neoclassical contracting and the agency costs of vertical integration. ${ }^{66}$

The critical insight of our stylized model of the Japanese system is that equity serves a larger purpose than in the Berle-Means corporate governance model. In the Berle-Means corporation, equity has governance rights because the holder of the residual profits interest has the best incentive to reduce agency costs; the right to control rests with those who stand to gain the most from efficient production. ${ }^{67}$ In contrast, in our Japanese model, a big slice of equity serves not just to encourage monitoring through ownership of the residual profits interest, but also to encourage relation-specific investment by reducing opportunism as well..$^{68}$

Traditional main bank monitoring can be reconfigured to fit this system. Creditors may invest through long-term relation-specific loans just as steelmakers will invest in a car factory by investing in machinery and at locations most useful for auto steel; both the creditor and the steelmaker will take stock positions in the automaker. An automaker that behaves badly will induce bank intervention. This may appear as American-style intervention of the residual equity holder to some, but we believe that the relationship is more complex, because it is

65. Dumping stock seems to be the implicit threat in Japan. See Roe, supra note 10.

66. In this regard, our model is similar to that of Berglof \& Perotti, supra note 44; see also WLLIAMSON, supra note 56, at 158-59; Gary P. Pisano, Using Equity Participation to Support Exchange: Evidence from the Biotechnology Industry, 5 J.L. ECON. \& ORG. 109 (1989). However, we extend the insight, albeit informally, to include a determination of what substantive arrangement is enforced-hard work or shirking-and the market circumstances necessary for the technique's success. See infra Part III(B)(1).

67. As one of us stated 10 years ago:

[The] description of shareholders as the "owners" of the corporation does not suggest that [their] role . . . flows, normatively, from their "ownership." It derives, rather, from the need for those holding the residual interest in corporate profits to have the means to displace management which performs poorly.... [T]his position is based on matters other than a preconception of the rights associated with "ownership"; indeed, if the statute did not provide for shareholders we would have to invent them.

Ronald J. Gilson, A Structural Approach to Corporations: The Case Against Defensive Tactics in Tender Offers, 33 STAN. L. REV. 819,834 n.56 (1981); see also Frank H. Easterbrook \& Daniel R. Fischel, Voting in Corporate Law, 26 J.L. \& ECON. 395 (1983); Eugene F. Fama \& Michael C. Jensen, Agency Problems and Residual Claims, 26 J.L. \& ECON. 327 (1983); Henry Hansmann, Ownership of the Firm, 4 J.L. ECON. \& ORG. 267 (1988).

68. Note that this treatment of the Japanese system contemplates the crisis intervention role that Aoki and Sheard assign the main bank. See supra text accompanying note 43 . In particular, our model assumes not only the familiar fact that main banks will own blocks of stock in their large borrowers, but also that the large borrowers will in turn own stock in the bank to assure that the bank does not behave opportunistically. This latter assumption appears to be consistent with the facts. For example, Sumitomo Bank is the largest lender to 11 of its 21 largest corporate shareholders and is a major lender in most other cases. Importantly, these borrower-shareholders control some of the bank's stock. Roe, supra note 10. 
deeply embedded in a system of contractual governance. The bank may deal with an opportunistic portfolio company. It does so, however, not just to maximize the returns of the residual equity holder-the American model-but also to protect the bank as a factor of production and provider of credit, and to protect the other industrial factors, in which the bank is a stockholder.

Even bank crisis intervention or actions as an ongoing monitor are partly acts of contractual governance, occurring in two dimensions. First, the bank is protecting its loan position, just as the steel company protects its long-term investment in machinery tailored to a customer's needs. Second, the bank, as an owner of stock in the related factors, is acting as their "agent." Main bank monitoring is not precisely analogous to monitoring by the residual equity holder, even when the bank is the residual equity holder, because the bank is also a factor provider and owns stock in other factor providers. The factor providers receive their returns on investment from the terms on which they provide their input, not just from the residual performance of the collective enterprise. ${ }^{69}$ In the Berle-Means model, corporate governance serves to assure that someone has the right incentives to monitor. In our stylized Japanese model, corporate governance serves to support contractual exchange. The multiple relationships-stockholder and creditor, stockholder and supplier-increase the incentives to intervene (by bundling up two advantages in the relationship) and decrease the costs (information flows through supplier contacts and stockholder contacts) when a related firm has problems. ${ }^{70}$

69. See infra text accompanying note 105 .

70. A similar theme is developed in Ito, Nezukuka Nihon-Ban M\&A-M\&A to Kabushiki Mochiai-no Honshi Tsu, Kin-yu, Dec. 1989; see Michael Gerlach, Business Alliances and the Strategy of the Japanese Firm, CAL. MGMT. REV., Fall 1987, at 126, 133 (cross-holdings "create a structure of stable, mutual relationships among trading partners"); KESTER, GOVERNANCE, supra note 8, at 26 (cross-holdings "“cement" business relationships among companies and serve as indicators of mutual long-term commitments").

Our model assumes complete cross-holdings and virtually complete intra-group trade. The reality is much less extreme. With respect to cross-holdings, Kester reports the percentage of reciprocally owned shares in the six intermarket keiretsu as follows:

$\begin{array}{ll}\text { Mitsui group } & 18.0 \% \\ \text { Mitsubishi group } & 25.3 \% \\ \text { Sumitomo group } & 24.5 \% \\ \text { Fuyo group } & 18.2 \% \\ \text { DKB group } & 14.6 \% \\ \text { Sanwa group } & 10.9 \%\end{array}$

Id. at Exhibit 6 (1987 data). However, if the denominator is limited to the total shares held by the top 20 shareholders in a company, the percentage of reciprocally owned shares increases substantially:

$\begin{array}{ll}\text { Mitsui } & 55.2 \% \\ \text { Mitsubishi } & 74.2 \% \\ \text { Sumitomo } & 68.8 \% \\ \text { Fuyo } & 49.2 \% \\ \text { DKB } & 42.3 \% \\ \text { Sanwa } & 32.8 \%\end{array}$

Gerlach, supra, at 133 (Table I). Additionally, large bank borrowers appear to own stock in their main banks. With respect to intragroup sales and procurement, Kester reports average intragioup sales among all group industrial companies in 1981 as $20.4 \%$ (29\% among original zaibatsu groups) and average intragroup procurement as $12.4 \%$ ( $18.6 \%$ among original zaibatsu groups), with a variance of between $8 \%$ and $30 \%$. KESTER, GOVERNANCE, supra note 8, at 17, Exhibit 4. Gerlach notes that such figures may understate actual 


\section{Illustration: General Motors and Fisher Body}

An example from America's vertical integration literature will illustrate our model. ${ }^{11}$ In 1919, GM needed auto bodies. Fisher Bodies needed a customer for its auto bodies. To build the kind that GM needed, Fisher had to invest in specific body-building assets. Fisher was unwilling to do this without assured purchases from GM. Without contract protection, GM could threaten to abandon Fisher once Fisher built the GM-specific plants unless Fisher lowered its price, making the GM-specific assets worthless. Once Fisher made the specific investments for GM auto bodies, GM could squeeze Fisher's price down to its variable costs (plus the value of Fisher's assets that could be redeployed away from GM's bodies). To protect Fisher, GM agreed to purchase its requirements of the specific body type for ten years from Fisher. This agreement opened up GM to the risk of exploitation by Fisher: GM was making an openended commitment to buy its requirements of the specified auto body only from Fisher. What would stop Fisher from raising its price? Price might be specified in a contract, but over ten years costs could change, making a specified price impossible. So, to protect GM, Fisher agreed to a formula by which the price would be calculated at Fisher's variable costs plus $17.6 \%$, with the $17.6 \%$ presumably representing the expected value of the specific assets to which Fisher was committing.

An unexpectedly rapid run-up in demand for the specified type of auto bodies made it worthwhile for Fisher to exploit the contract's formula to hold up GM. The unexpected run-up in demand for Fisher-type bodies made it worthwhile (from an integrated perspective) for Fisher to build new capitalintensive plants and locate them next to GM, but Fisher refused to do so and wanted to be paid under the contract formula. With expanded demand, capitalintensive plants would have been cheaper than the labor-intensive means Fisher used, but capital-intensive production disfavored Fisher under the contract. Eventually GM solved its problem by buying up all of Fisher's stock.

In our abstract model, Fisher's unexpected ability to exploit GM might have been mitigated by extensive cross-ownership. Fisher would have been $5 \%$ owned by GM, $5 \%$ owned by a steel firm, $5 \%$ owned by an automotive paint and fabric firm (DuPont), and $20 \%$ owned by a coalition of banks, one of which would have been a "main bank" for this network. In such a setting, Fisher could not have readily exploited the unexpected loophole because a coalition of owners could displace Fisher's senior management. Ex ante, GM and Fisher might not

intragroup sales and procurement by excluding transactions within vertical groups inside the intermarket keiretsu. Gerlach, supra note 48 , at 12-13, 185-91.

71. We draw this example from Benjamin Klein's description. See Benjamin Klein, Vertical Integration as Organizational Ownership: The Fisher Body-General Motors Relationship Revisited, 4 J.L. ECON. \& ORG. 199, 200-02 (1988). 
have even bothered with the detail they put into the contract, a contract that ex post turned out to be insufficiently detailed.

The end result for the GM-Fisher Body problem was complete vertical integration, raising a serious problem for our model: why is vertical integration not a general solution for investments in relation-specific assets? Shouldn't the factors always choose vertical integration-complete, not partial ownership-as the full solution?

We take this point seriously and do not have a complete answer. Our hypothesis - suggested by GM's subsequent history -is that something else must be traded off. First, complete vertical integration raises the agency problems of large organizational structures, requiring costly investments in internal monitoring. GM's bloated bureaucracy and recent poor performance may be the result of "excess" vertical integration. Second, the cross-holding/crossexchange structure differs from complete vertical integration. There is some resort to contract. The trading relationship between members of even a vertical keiretsu is not exclusive. The Japanese corporate governance system is said to be

an attempt to secure the best of two worlds. By tying themselves to one another in groups, yet eschewing outright ownership and control, Japanese corporations have been able to exploit some of the high-powered incentives of the market that derive from independent ownership of assets, while relying on selective intervention by key equity owners to adapt contracts to new circumstances as needed. ${ }^{72}$

The ability of even the completely vertically integrated firm to use outside suppliers to test the internal division somewhat weakens the distinction. If the internal division does not measure up, it can be disbanded. One weakness of complete vertical integration, however, is that if the relational failure goes the other way-the division performs, but the enterprise as a whole slackens-the division cannot easily detach itself from the slackers and migrate to a highperformance company. ${ }^{73}$ With keiretsu partial cross-ownership, that kind of migration-and the incentives it provides others in the organization-is possible. $^{74}$

72. KESTER, JAPANESE TAKEOVERS, supra note 8, at 80 . Roe argues that the Japanese cross-ownership flattens authority in the large firms compared to the hierarchical pyramid in the large American firm. Flat authority may sometimes perform better than a pyramid of authority. See Roe, supra note 10 .

73. There is surprising mobility from one keiretsu to another. See Roe, supra note 10.

74. We do not for our purposes here need to identify and quantify the exact value of hybridization of contract and organization in Japan. It is indeed possible that the difference is one of form (although we doubt it), arising solely from the Japanese ban on pure holding companies after World War $\mathbf{U}$. For present purposes we only claim that the Japanese form is a hybrid between contract and organization, which may have some efficiency advantages. 


\section{B. But What About Monitoring? Product Market Competition as the Catalyst that Makes the Hybrid Work}

Our stylized model of the Japanese corporate system, in which cross-holdings of equity serve to support exchange rather than to provide incentives for minimizing agency costs, is not yet complete. By reducing opportunism, crossholdings may support the investment in relation-specific assets necessary to efficient production. Acquisition of these assets, however, will not guarantee efficient production. Even an optimal amount of relation-specific assets must be effectively employed. And here, the skeptic will remark, is where the contractual governance model falls short. Monitoring - a corporate governance system directed at reducing agency costs-could still be necessary to assure that those in charge of employing the relation-specific assets work hard enough to maximize the return on investment. Without it, the cooperative arrangement supported by cross-holdings may cease to support efficient production, instead deteriorating into a cooperative arrangement to protect a collective decision by the various factor providers to live the good life: I won't monitor you if you won't monitor me. ${ }^{75}$

In the corporate governance model, monitoring is conducted, albeit imperfectly, by the residual owners. And in the absence of an alternative to a residual owner at the center of the corporate governance model, a contractual governance model also will not work. Thus, the contractual governance model we have proffered could lead to everyone working hard or no one working hard, or any point in between. Understanding the success of the Japanese model requires that we understand what helps prevent cooperative shirking. ${ }^{76}$

\section{Competition as Catalyst}

The most elegant monitoring mechanism is intense product market competition. We hypothesize that product market competition and relationspecific investment could interact to generate a powerful monitoring structure.

75. Coffee makes a similar point:

[T] he very structure of the keiretsu seems designed to ensure weak monitoring. Because the main bank holds an ownership level that is below five percent by definition, it must secure the consent of its fellow keiretsu members before it can take disciplinary action or remove senior management. Yet these other members share a common interest in restricting main bank interventions in the internal affairs of each member to occasions in which the demonstrated delinquency of a member firm threatens the keiretsu as a whole.

Coffee, supra note 29 , at 1300 .

As developed in the remainder of this section, the critical issue is identifying why the structure of the keiretsu does not ensure weak monitoring.

76. One of us encountered the multiple equilibria problem years ago when he left his two daughters home without a babysitter for the first time. The children were told that each would babysit the other, the parents assuming that a monitoring equilibrium would result. As the children later recounted, almost immediately after the parents left, one child asked the other if she could have a sweet. The other child answered in the affirmative and made a reciprocal request-a shirking equilibrium. 
Each factor provider has made a substantial relation-specific investment and must bear a substantial nondiversifiable risk in that investment. Everyone suffers if the joint effort does not succeed in the product market. Thus, competition with producers outside the keiretsu gives each factor provider an incentive to perform effectively. ${ }^{77}$ Additionally, the joint character of the production creates an incentive for factor providers to cross-monitor each other as a check on free riding. Because a joint product's success in the product market depends on the quality of each factor, each provider's relation-specific investment is hostage to each of the other's performance; shirking by any factor provider endangers all. Each factor provider, therefore, has an intense interest in the other providers' performance.

Product market competition, then, gives each factor provider an incentive both to perform and to monitor the others' performance. In addition, the factor providers occupy a unique informational position. Because each factor monitor is also a producer with relational contacts, it need not invest significant new resources in information when acting as monitor: It already knows (or almost knows) what the target is doing by interacting in the production process. Joint production-of information and goods-yields factor providers real time information about their co-venturers' performance. A factor provider using another provider's parts quickly identifies any decrease in quality. Similarly, a just-in-time inventory system, while economizing on storage space and capital costs, also measures factor performance on a daily basis; the supplier's or assembler's inability to perform quickly becomes apparent. ${ }^{78}$ Moreover, an opportunist seeking to shirk at a supplier's expense cannot capture the full benefit of its opportunism; because it owns a slice of the supplier's stock, it will bear some of the cost, thereby reducing opportunistic incentives. Finally, the movement of executives among factor providers, said to be commonplace within the keiretsu, ${ }^{79}$ also provides for monitoring.

In our model, these aspects of the Japanese system do not exist for the primary purpose of monitoring by the residual owner, although that monitoring may help them survive. ${ }^{80}$ Rather, cross-ownership and contractual relations facilitate monitoring if competition in the product market provides the incentive to monitor. In this view, monitoring is not only an intermittent phenomenon, carried out by a board of directors or even a financial intermediary when the situation so deteriorates that those at the top of the structure learn of the crisis.

77. It is a familiar pattern in the principal-agent literature that an agent must bear nondiversifiable risk to create an incentive, but that the very act of creating the incentive shifts risk to an inefficient bearer.

78. We realize that much just-in-time production often involves delivery by smaller, closely held firms to larger publicly held firms. In such a relationship, the smaller supplier probably does not own stock in the assembler.

79. See Gerlach, supra note 48 , at $173-74$.

80. The just-in-time inventory system, for example, is said to have been a response to the 1973 energy shock. See Takao Komine, Structural Change of Japanese Firms, I9 JAPAN J. ECON. STUD. 79, 80 (1991). Similarly, cross-ownership increased to prevent takeovers. See infra text accompanying notes 93-95. 
Instead, inter-factor monitoring is woven into the fabric of production. ${ }^{81}$ Put differently, product market competition and relation-specific investment transform the production process into a low cost monitoring process. Joint production yields information about performance, and thus performance monitoring.

Thus, product market competition is central to our stylized model of the Japanese system as one of contractual governance. ${ }^{82}$ In the presence of competition, the system encourages investment in relation-specific assets which, in turn, provides both the incentive and the information for inter-factor monitoring. Centralized monitors, such as a board of directors or, as we will argue shortly, even a financial institution, cannot always get this information as quickly. ${ }^{83}$

This critical role of product market competition to the success of the Japanese contractual governance model suggests a means of testing our stylized model's consistency with observed facts. For our model to be consistent with the actual Japanese system, superior Japanese industrial performance should depend on the presence of product market competition rather than on the existence of a few dominant companies: Japanese companies should succeed internationally in industries with substantial competition and fail in industries when competition is less vigorous. This appears to be the case. Michael Porter reports that "[v]irtually every significant industry in which Japan has achieved international competitive advantage is populated by several and often a dozen or more competitors." 84 The converse is also true: "While domestic rivalry is intense in virtually every industry in which Japan is internationally successful,

81. Professors Aoki and Sheard also stress the importance of monitoring as a byproduct of a primary commercial relationship in connection with main bank crisis monitoring. They note that a company's main bank also carries its principal payment settlement accounts, the primary method of payment for intercompany transactions in Japan. By observing levels in these accounts, the bank can monitor day-to-day cash flows of bank borrowers, including their dealings with suppliers and distributors. See Aoki, Ex Post Monitoring, supra note 43; Aoki \& Sheard, supra note 43.

82. Some have observed that in the American corporate governance system, product market competition may substitute for the market for corporate control in providing an incentive for efficient performance. Of the companies that proposed dual class recapitalizations, which, by placing absolute voting control in the hands of management or a dominant shareholder group, eliminated the influence of the market for corporate control, over half were relatively young companies in fast growing markets with negative cash flows-that is, companies facing strong product market competition. See Ronald J. Gilson, Evaluating Dual Class Common Stock: The Relevance of Substitutes, 73 VA. L. REV. 807, 824-32 (1987); Kenneth Lehn, Jeffry Netter \& Annette Poulsen, Consolidating Corporate Control: Dual-Class Recapitalizations Versus Leveraged Buyouts, 27 J. FIN. ECON. 557 (1990) (empirical test of Gilson hypothesis).

83. We do not mean that inter-factor monitoring is always faster. Inter-factor monitoring of serious breaches will require transmission up through the factor's organization to the board (or its equivalent). Then that board-or senior management-will deal with the breaching factor's senior management. This transmission will, we suppose, usually be as slow as the boand's monitoring of internal problems. The difference we see is that sometimes inter-factor monitoring is faster and transmission up to the board is unnecessary. The assembler's mid-level foreman sees bad parts and tells the supplier's mid-level foreman that the rejection rate is rising, leading the supplier to investigate and change. No one contacts any board of directors.

84. MICHAEL E. PORTER, THE COMPETITIVE ADVANTAGE OF NATIONS 411-12 (1990). We realize that competition could directly spur superior performance, without going through the organizational mechanisms we model here. 
however, it is all but absent in large sectors of the economy. ... Almost none of these ... industries ha[s] ever achieved international success. ${ }^{285}$

\section{Vertical and Horizontal Keiretsu: Helping to Explain Some Performance Differences}

Taxonomists divide Japanese keiretsu into vertical and horizontal types. Our contractual governance story best fits the vertical keiretsu, in which companies tend to be related, such as suppliers to an end-producer. Companies in the horizontal keiretsu are more often unrelated, with looser supplier-customer relations. Since there is cross-selling even in the horizontal keiretsu, however, our story has a role to play there as well.

Our contractual governance model could also help explain a recurrent puzzle among those observing the large Japanese firm: the new firms of the vertical keiretsu-sometimes called the independents-have slightly better measures of performance than the old-line horizontal keiretsu. ${ }^{86}$ Some might suggest that the banks' role is detrimental. This does not seem to be so, however, since banks' blocks of independents' stock are slightly larger than their old-line keiretsu blocks. ${ }^{87}$ Differing main bank ownership levels cannot explain the slightly different performance levels. One explanation is that vertical keiretsu are new firms in new, initially profitable industries and have not yet reached their long-run equilibrium. Another is that the vertical independents have had families with significant ownership stakes-the Toyoda family in Toyota, the Matsushita family in Matsushita, Akio Morita in Sony. Family ownership and financial ownership give these firms two hierarchical monitors.

We offer a third explanation. These independents are not free-standing corporations, like GM or IBM. As members of vertical keiretsu, consisting primarily of companies in related industries, suppliers and customers, ${ }^{88}$ they should exhibit the productive features we examine here better than old-line horizontal keiretsu. With completely unrelated keiretsu firms, monitoring would be slower, from the top, not rapid as among related production factors. Vertical keiretsu should provide more rapid monitoring. Thus in our story, vertical keiretsu have three strong brands of monitoring: top-down by institutional shareholders, top-down by family shareholders (sometimes), and across companies via contracting. Old-line companies will be weaker in the third. The

85. Id. at 413. Komine also stresses the importance of domestic competition to Japan's international success. Komine, supra note 80 , at 82-84. For our purposes, it matters little whether the competition is domestic or international, as Japanese firms seek export markets and must compete. The point is that competition activates the model, pushing the firms away from mutual protection of slothfulness.

86. See Coffee, supra note 29 , at 1301 .

87. See Roe, supra note 10 , at app.

88. See Gerlach, supra note 48 , at $12-13$. 
strengthened form of contractual governance in the independents may explain their slightly superior performance.

\section{Is Competition Enough?}

If competition triggers good performance in the keiretsu and reduces shirking, the next question a skeptical reader might ask is, why isn't competition enough? Why wouldn't competition without cross-ownership induce superior performance?

To a large extent, of course, it does. Firms losing customers eventually react. Some slower reacting firms disappear. We have no way of measuring how much competition acts directly and how much it acts through the organizational features we analyze. The point, however, is that cross-ownership can speed up and deepen the organizational changes that competition induces.

A deteriorating firm loses customers. But with many long-lived assets in place, no particular need to access capital markets, and senior managers who seek a quiet life in the three years until their retirement, a firm facing-only competitive constraints does nothing. A group of owner-suppliers or ownercustomers, however, is not yet slothful. Such a group wants a shirking firm to produce quality components for the group. A group of owner-customers has two incentives to prevent a slothful supplier from deteriorating: first, the group wants a good component, now; second, it wants to protect the value of its investment in the decaying firm. Moreover, the group's stock investments gives it another method to bring about quick change: it can withdraw its purchases (the pure competitive solution) and it can use its stock to bring about management changes. It has, in the standard terminology, the options of exit and voice. $^{89}$

\section{IMPLICATIONS FOR COMPARATIVE CORPORATE GOVERNANCE ANALYSIS}

The measure of an analytic model is whether it helps us better understand the world we observe. In this Part, we consider (1) the implications our contractual governance conception of the Japanese corporate system has for understanding the main bank's role, (2) the significance of the antitakeover role of cross-holdings, (3) the public shareholder's role in companies with significant cross-holdings, and (4) the stability of the Japanese corporate structure. We then turn to the American corporate governance system. Does this perspective on Japanese governance help us evaluate current proposals seeking to reform the

89. See generally ALBERT O. HIRSCHMAN, EXIT, VOICE, AND LOYALTY -RESPONSES TO DECLINE IN FIRMS, ORGANIZATIONS, AND STATES (1970). 
American system by incorporating institutional features considered characteristically Japanese?

\section{A. Implications for Understanding the Japanese Corporate Governance System}

\section{Understanding the Role of the Main Bank}

The Japanese main bank is often seen as a monitoring paragon: solving the Berle-Means quest to bridge the separation of ownership and control, and internalizing the market for corporate control by intervening in its client firm's operations when it detects deterioration in performance that threatens the firm's economic viability. Our model of a Japanese contractual governance system, in contrast, allows a more limited role for the bank, as residual owner. It need not be the first line monitor; factor providers conduct real time monitoring during the production process. ${ }^{90}$

This account of main bank monitoring's fit with our model's productionbased monitoring is consistent with Professors Aoki and Sheard's main-bankcentered view of Japanese corporate governance. ${ }^{91}$ They recently argued that the main bank operates primarily in financial crisis, giving management and employees an incentive to perform efficiently: the bank frees management from capital market discipline and efficient performance frees management from bank discipline. The mere existence of a coalition of banks with large stockholdings may motivate managers to avoid a crisis that will trigger bank intervention. In addition, the cross-holdings among factors of production may help managers avoid falling behind competitors and the bank action such a lag would precipitate.

The main bank system has also been heralded as a substitute for takeovers. We do not challenge the view that institutional influence, if structured properly, could be a replacement for, or indeed be superior to, takeovers. And by inducing managerial change, main bank crisis intervention replicates some of takeovers' desired effects. Also, Japanese managers may work hard to avoid a crisis that would trigger activity from an otherwise inactive group of stockowning banks, similar to the serious efforts of some American managers to avoid triggering a takeover offer. The Japanese managers' goal of keeping banks quiet could induce good management even without hands-on bank monitoring.

90. Professor Aoki notes that some 400 banks had extended credit to Chrysler at the time of its near bankruptcy. In the absence of delegated monitoring, no bank had the incentive to gather information necessary to intervene early. Moveover, an enormous coordination problem impeded capturing the lenders' attention before disaster was imminent. Aoki, Toward an Economic Model, supra note 8, at $15 \mathrm{n} .7$. A focused group of lender-stockholders constantly interacting with Chrysler's senior managers, suppliers, and customers might have intervened earlier and more effectively.

91. See Aoki, Ex Post Monitoring, supra note 43; Aoki \& Sheard, supra note 43. 
That said, we believe that the main bank system has yet to be shown as a close, proven substitute for much of the 1980's antitakeover activity in the United States. The U.S. takeover market of the 1980's primarily broke up the conglomerates of the 1960's and early 1970's, whose principal problem was not financial peril but the misspending of free cash flow. In contrast, the Japanese main bank of the 1950's, 1960's, and 1970's had little experience in overseeing the effective utilization of free cash flow. Few Japanese companies had free cash flow: they were expanding their core business, reinvesting profits in that core business, and seeking financing for further expansion. In this sense, the main bank had an easy job; the hard job is only now beginning, as more large Japanese firms acquire enough cash to be free of dependence on bank lenders. Whether the banks' dual role-as stockholder of and lender to Japanese firms-will induce firms to fall less deeply into free cash flow pitfalls remains as a fuller test of the claim that main banks internalize the market for corporate control. ${ }^{92}$ Our point here is not that the main bank failed as cash flow monitor in Japan; our point is that Japan only now is confronting the problem.

\section{Understanding the Significance of Cross-Holdings' Antitakeover Role}

Keiretsu cross-holdings are also an antitakeover device. ${ }^{93}$ Cross-holdings make an external takeover impossible, and the "possibility of bank takeover" is said to substitute for the corporate control market in enforcing managerial discipline.

Our model treats cross-holdings as a means to prevent one factor provider's opportunistic behavior following relation-specific capital investment by others. An external takeover threat has no role in this explanation. What accounts for the conflict?

Part of the original motivation for cross-holdings was to secure protection from takeovers. Cross-holdings increased in response to the sale, from 1967 through 1969, of stock in "Kyodo Shoken"-a company established by the Japanese government to acquire stock held as inventory by financially troubled brokerage houses. Depressed stock prices and the Kyoda Shoken overhang created takeover fears. Increased cross-holdings were said to be the response. ${ }^{95}$ The motivation for acquiring cross-holdings, however, may differ from the

92. Indeed, cross-holdings may have perverse effects when business is, or should be, contracting. First, the presence of free cash flow can reflect reduced product market competition, thereby lowering a barrier to mutually accepted shirking. In addition, customer and supplier shareholders may be more willing to accept expansion during a business decline than pure shareholders. Perhaps the financial shareholders (banks and insurers) will intervene in a role approaching a pure Berle-Means monitor, but that is in fact the question to be seen.

93. See, e.g., Sheard, supra note 34, at 425; JACK MCDONALD, ORIGINS AND IMPLICATIONS OF CROSSHOLDINGS IN JAPANESE COMPANIES (Graduate School of Business, Stanford University Technical Note No. 79, 1991).

94. See Aoki, Toward an Economic Model, supra note 8, at 15.

95. MCDONALD, supra note 93 , at 3-4. 
function the holdings came to perform. The contractual benefits of cross-holdings might not be obvious or easy to construct. A catalyst-fear of takeovers-might have been the impetus for cross-holdings; thereafter, the positive functions were seen, or survived.

The pattern of contractual governance that our model represents did not spring forth, fully-formed, at a single point. For example, our model assumes a production process in which efficiency requires substantial relation-specific investment by all parties. Both Aoki ${ }^{96}$ and Piore and Sabel ${ }^{97}$ associate the Japanese system's success with a shift in demand, leading to a responsive shift in the production process that in turn requires greater relational specificity with respect to both industrial and human capital. Multiple products and shorter product cycles necessitate flexible production machinery and more flexible, highly trained workers; the combination leads to relation-specific investment. It makes little difference, however, why the cross-holdings were acquired; once the character of the production process began to change in the direction of greater investment in relation-specific assets by all parties, cross-holdings helped to support it.

Observers of the American corporate governance system should not be surprised that environmental change can dramatically alter the governance function of a corporation's structural features. It is now commonplace to stress the important role institutional investors, especially pension funds, will play in future corporate governance; the extraordinary growth in institutional holdings could, some say, help bridge the separation of ownership and control by reaggregating shareholdings. ${ }^{98}$ It is clear, however, that a desire to improve corporate governance did not motivate the growth of pension funds. Rather, that growth reflects both a post-World War II decision in the United States to provide for retirement security through private pension funds instead of through an expansion of Social Security, ${ }^{99}$ and the substantial tax incentives for individuals to use pensions for savings. ${ }^{100}$ But whatever the original motivation behind the growth of pension funds in the post-War United States, their present function is central to the current corporate governance system.

The original motivation for cross-holdings may be beside the point. Our model hypothesizes what their current economic function may be.

96. Aoki, Toward an Economic Model, supra note 8, at 7-10.

97. PIORE \& SABEL, supra note 30, at 223-26.

98. See supra text accompanying notes 26-29; Black, Agents Watching Agents, supra note 7, at 813-14; Black, Value of Institutional Investor Monitoring, supra note 7, at 896; Gilson \& Kraakman, supra note 7, at 892-94.

99. See WILliam GRAeBNER, A History OF RETIREMENT 215-21 (1980).

100. See, e.g, Deborah M. Weiss, Paternalistic Pension Policy: Psychological Evidence and Economic Theory, 58 U. CHI. L. REV. 1275 (1991). 


\section{Understanding Japanese Contract}

In our view, there may be a more fruitful area of historical inquiry than Japan's takeover history. We hypothesize that Japan's path of development led it to rely more on relational cross-investments than on contingent contracts. Our hypothesis depends on our finding either weak law enforcement or a reluctance to use the courts. At the turn of the 19th century, when large scale enterprise became technologically possible, Japan imported key elements of its legal system from Prussia and France. ${ }^{101}$ Perhaps the Japanese were reluctant to use the imported system tenaciously. If so, vertical integration, rather than contract, could have guided large enterprises. And indeed there were large vertical organizations, the zaibatsu. Moreover, Japanese culture is said to resist the use of legal action $^{102}$ and to resist discussing unharmonious conflict-a discussion that writing a contingent contract requires. These cultural traits handicap the effective use of a detailed contract.

If law is weak, then alternatives must be found. The zaibatsu helped, and after their post-war prohibition, the partial relationships of the keiretsu also-help. An alternative to the bond indenture or hundred-page supply contract is partial stock ownership.

We posit three contractual problems for modern economies to solve: debt governance, supply contract governance, and corporate equity governance. In the United States, a well-developed legal system makes it possible to achieve passable debt and supply contract governance through explicit contracts. Although the completely contingent contract is unattainable, a passable contract-the bond indenture, the loan agreement, the hundred-page supply contract - can be written and enforced without impinging cultural norms. Two contractual governance problems are tolerably controlled in America; only viable corporate equity governance contracts cannot be written.

Contrast Japan. If neither the bond indenture nor the supply contract can be effective because of the nature of the Japanese legal system or culture, some mechanism to foster long-term relations must be constructed. In the course of constructing such a mechanism, Japan also reduces the corporate governance problem. ${ }^{103}$

101. Karel Wolferen, THE Engma of JAPANEse POWER 208 (1991).

102. Id. at 315 .

103. This is an economy-of-scale argument. Japan has three contractual governance problems to solve with cross-ownership. Cross-ownership may have costs, like illiquidity, see Coffee, supra note 29, at 1318-21, but in Japan the gains are in three dimensions. In America, the costs loom larger, because the gains come primarily in one dimension.

Without well-developed relational contracting doctrines, enforcement costs may be high in Japan. If the standard approach is to enforce the four comers of the document without interpretive understanding, contracting parties may be forced to choose between the rigidities of the four-corners contract and the looseness of the relational structure. American contract law may give American suppliers and customers an alternative. We also recognize that these legally-determined results could explain not only the origin of the cross-holdings, but also part of their continuing rationale. 


\section{Understanding the Role of Public Shareholders in Japan}

In our model of a contractual governance system, factor providers' shared control, accomplished through cross-holdings, does not diminish the returns to any other party. This simple depiction of the system contemplates that only factor providers are shareholders. In actuality, keiretsu members also have public shareholders, holding about one-quarter of the stock. This has caused some commentators to question whether factor providers' demand for higher than market-clearing wages - growth more than price maximization with the pay-off to creditor-stockholders in excessive debt-comes at the expense of individual stockholders. ${ }^{104}$

Our model suggests an explanation other than exploitation for the implicit difference between the value of controlling factor provider shares and the value of noncontrolling public shares. Shareholders will unanimously favor maximizing the corporation's share value when separation applies: that is, when the corporation's decisions affect shareholder wealth only through their impact on the value of its shares. In our model, however, separation does not apply for factor providers making relation-specific investment. In order for factor providers to receive a return that reflects the specificity of their investment, the firm by definition must maximize something other than share value. Simply put, the factor providers make an additional investment for which they expect an additional return, a return not provided by maximizing shareholder return.

An additional step is necessary to complete the argument: noncontrolling shareholders may well approve of the nonmaximizing behavior. So long as the "extra" return to factor providers is less than the increased productivity resulting from the relation-specific investment, noncontrolling shareholders are better off than if factor providers maximized share value but did not make the investment. Moreover, if public shareholders hold pieces, directly or indirectly, of each factor, they will want to maximize aggregate productive efficiency, net of costs to nonstockholding factors (like employees). Thus, our model suggests that to demonstrate exploitation of public shareholders requires more than the observation that keiretsu companies do not maximize share value; it requires the stronger claim that share value is lower than if the relation-specific investments were not made at all. In other words, public shareholders are only

104. See, e.g., RYUTARO KOMIYA, THE JAPANESE ECONOMY: TRADE, INDUSTRY, AND GOVERNMENT $167-70,172-73,177,180$ (1990); see Coffee, supra note 29, at 1298. Contrary to the commentators, we believe that the "higher" in higher than market-clearing wages must be judged in terms of productivity. If "higher" wages yield greater productivity, or are a needed component in a system yielding productivity, then the "higher" wages may benefit stockholders. We leave pursuit of this analysis for others, who might begin with George A. Akerlof \& Janet L. Yellen, The Fair Wage-Effort Hypothesis and Unemployment, 105 Q.J. ECON. 255 (1990). In the text we generalize this labor productivity argument. 
exploited when they receive no return from the increased productivity resulting from the factor providers' investment. This showing has yet to be attempted. ${ }^{105}$

\section{Understanding the Stability of the Contractual Governance Model}

The familiar account of the Japanese corporate governance system seems to assume that the implicit contract it describes-assured employment, protected by cross-holdings from breach by takeover, and monitored by the main bank to assure viability -is stable. No party will break the covenant because some unspecified implicit remedy-perhaps reputation-deters it. Our model suggests a more precise analysis.

In Part III, we described cross-holdings as protecting against opportunism when, in an unexpected state of the world, fortune randomly sets up a factor provider with an opportunity to exploit. What happens, however, when an event occurs that permanently devalues a factor provider's relation-specific investment? In that circumstance, the factor providers in our model will unfavorably alter the participation of the unlucky provider. While the coalition will prevent one lucky factor provider from exploiting the group, it will not protect a single unlucky provider from the consequences of a long-term shift in fortunes.

This analysis calls into question the claim that American antitakeover protection (or the Japanese main bank) is necessary to support factor providers' relation-specific investment. Imagine that a hostile bidder confronts a target whose factor providers receive a return on relation-specific investment. If continued relation-specific investment by a particular factor provider is no longer valuable-that is, if the factor provider's special contribution has been permanently devalued-the hostile bidder will cut it off. But so will participants in a contractual governance system. A contractual governance perspective thus suggests that an implicit contract justification for antitakeover protection requires more careful specification. ${ }^{106}$

\section{B. Evaluating Reform Proposals for the U.S. Corporate Governance System}

In recent years, the Japanese corporate governance system has captured the vision of those seeking to reform American corporate governance. Japan appeared

105. Professors Coffee and Ramseyer argue that the main banks' co-insurance role cannot be valuable to the noncontrolling shareholders "because shareholders can diversify to protect themselves from losses and so would not want expensive insurance purchased from banks at the price of above-market interest rates." Coffee, supra note 29, at 1298; see Ramseyer, supra note 38 , at 112 n.66. But shareholders ought not to be the beneficiary of the insurance; it is the other providers of relation-specific investment who are protected. Shareholders can diversify risk; these providers cannot. Insurance induces the proper level of relation-specific investment which, in turm, benefits noncontrolling shareholders so long as their share of the productivity gain from the investment exceeds the above market portion of the interest rate.

106. See Ronald J. Gilson, The Political Ecology of Takeovers: Thoughts on Harmonizing the European Corporate Governance Environment, 61 FORDHAM L. REV. 101, 129-31 (1992) (providing more detailed criticism of implicit contract arguments against takeovers). 
to have solved the Berle-Means problem. ${ }^{107}$ Yet quick, complete institutional imitations are difficult. ${ }^{108}$ We next consider one such reform effort-the LBO association, said to be arising in the shadow cast by the eclipse of the public corporation-whose proponents hold out the Japanese system as evidence of their effort's promise. We also briefly consider the segments of the U.S. economy identified by our model as potentially suitable recipients of a contractual governance transplant.

Our model suggests that the Japanese system differs from the LBO association in its specifics; as a result, it offers less support for the reform effort than is claimed. It is important to stress, however, that we do not mean to reject the reforms themselves. Rather, we argue only that the reforms must be justified by their fit with our system, not by their limited resemblance to a very different Japanese system.

\section{The Keiretsu and the LBO Association}

Michael Jensen has advanced the LBO association as a successor to the public corporation. ${ }^{109}$ Jensen describes LBO associations as having three components: (1) a sponsoring partnership that organizes highly leveraged goingprivate transactions and advises and monitors post-transaction target management on a cooperative and ongoing basis; (2) target company managers who remain post-transaction and who receive a substantial equity stake to "incentivize" their performance; and (3) institutional investors who provide the limited partnership with the debt and equity to make the acquisition. ${ }^{110}$ These entities, Jensen argues,

have a fundamental affinity with Japanese groups of firms called "keiretsu." LBO partnerships play a dual funding and oversight role that is similar in many ways to that of the main banks in the Japanese keiretsu. Like the main banks, which typically hold significant equity stakes in their corporate borrowers, the leaders of the LBO partnerships hold substantial amounts of equity in their companies and control access to the rest of the capital. Further like the Japanese banks, the LBO

107. See TASK FORCE REPORT, supra note 1, at 7-8, 66, 189-90, 193-94, 286; Porter, supra note 2.

108. See Roe, supra note 10; Coffee, supra note 29, at 1318-19, 1324-27. Roe emphasizes that the bank as monitor-whether through residual equity-holding or as part of a contractual governance system-cannot easily be constructed in the United States. Due to historical (and some current) product and gengraphic restrictions, American banks are too weak and too small compared to Japanese banks. Deposit insurance is too deeply embedded in the American system; massive bank ownership cannot work well without solving the problems arising from deposit insurance. But since we have had many more compelling reasons than corporate governance to solve these deposit insurance problems and have not done so, there is little reason to be optimistic about unleashing banking institutions. There are possibilities, Roe argues, for other financial institutions. Coffee believes that the current reward systems for institutional fund managers do not reward superior long-run performance; he believes institutions as currently structured need so much liquidity that they could not undertake the long-term investments said to be commonplace in Japan.

109. See Jensen, supra note 3 , at 61 .

110. Id. at 68 . 
partners are actively involved in the monitoring and strategic direction of these firms. ${ }^{11}$

Finally, like the Japanese banks, the LBO association privatizes bankruptcy. ${ }^{112}$

In our view, the $\mathrm{LBO}$ and keiretsu have one similarity, but two significant differences. Jensen identifies the similarity: financial institutions play a large role in both. One difference, however, is that the Japanese bank's role is embedded in a deeper system of relational cross-holdings. Industrial companies with relation-specific investments provide much of the monitoring and one-third of the cross-ownership in the keiretsu. In contrast, they provide none of the monitoring or cross-ownership in the LBO. The contractual governance structure among factors of production, and its dependence on product market competition, is critical to the keiretsu, but absent in the LBO. ${ }^{113}$

Secondly, they differ in that the LBO association is best suited to companies with substantial shares in mature markets that generate free cash flow. This is precisely the opposite of the product market conditions that, we argue, are critical to the success of a contractual governance system dependent on new relational investments, and precisely the opposite of the crisis conditions under which Professors Aoki and Sheard claim the main bank has so far played its real role. ${ }^{114}$ The main bank's active role appears now to be crisis intervention; ${ }^{115}$ its primary noncrisis role is to hold a large block of stock that will become active if managers allow a crisis to develop. We do not want to demean the potential effectiveness of large but usually passive shareholders-as the main banks may be when their credit-monitoring dissipates-if managers fear their actions may activate such shareholders. ${ }^{116}$ But this type of monitoring differs quite substantially from the LBO association's hands-on real time monitoring. In our view,

111. Michael C. Jensen, Corporate Control and the Politics of Finance, J. APPLIED CORP. FIN., Summer 1991, at 13, 22.

112. Michael C. Jensen, Active Investors, LBOs and the Privatization of Bankruptcy, J. APPLIED CORP. FN., Spring 1989, at 35 (statement before House Ways and Means Committee, February 1, 1989); Jensen, supra note 3 , at 73 .

113. At least for pre-1986 transactions, the LBO association did appear to privatize bankruptcy. Transactions occurring after 1985 reflected changes in structure that made such privatization more tenuous. First, publicly held debt replaced privately placed debt, increasing the negotiating costs of consensual reorganizations. See Mark J. Roe, The Voting Prohibition in Bond Workouts, 97 Y ALE L.J. 232, 236-43 (1987). Second, strip finance, which mitigated intrafirm bargaining in the event of distress, also declined after 1985; and, finally, principal payments on senior bank debt were accelerated. See William F. Long \& David J. Ravenscraft, Decade of Debt: Lessons from LBOs in the 1980s, in THE DEAL DECADE (Margaret Blair ed., forthcoming 1993); STEVE N. KAPLAN \& JEREMY C. STEIN, THE EVOLUTION OF BUYOUT PRICING AND FINANCLAL STRUCTURE IN THE 1980S (Center for Research in Security Prices, Graduate School of Business, University of Chicago Working Paper No. 327, 1991).

114. See supra text accompanying note 43 .

115. Id. The reason for the difference in monitoring roles may be found in the source of the power to monitor; unlike the main bank, which owns no more than $5 \%$ of a client company, the LBO association has absolute voting control over its operating entities.

116. Kester reports semiannual meetings between managers and bankers where the managers report on recent performance but do not submit budget and future plans to the banks. KESTER, JAPANESE TAKEOVERS, supra note 8, at 194-97. 
the main bank's crisis role is more analogous to that of Warren Buffett's Berkshire Hathaway-large stakes but major action only in crisis-than to the LBO association. ${ }^{117}$ Finally, the amount of stock that the main banks own appears to be considerably less than the amount the LBO association owns. The main bank typically owns $5 \%$ and can usually put together a small coalition of other financial institutions that will reach $20 \%$. or so. In contrast, the LBO association frequently owns all of the company's stock.

The point of this analysis is not to enter the debate over Jensen's claim that the LBO association should replace the public corporation. ${ }^{118}$ Rather, the point is that an analysis comparing the LBO and the keiretsu is not directly illuminating, because such an analysis implicitly relies on the belief that the Japanese corporate governance system is a response only to the Berle-Means problem. The LBO association's efficiency as a governance structure depends on its fit with the American system of weak financial intermediaries, weak crossholdings among factors of production, and strong enforcement of contracts. The success of the Japanese main bank, which operates in circumstances very different from those in the United States, only illuminates the American inquiry to the extent that it suggests that the American system of corporate governance is not inevitable.

\section{Where Might the Japanese Model Provide Guidance?}

Though not perfectly transferable, the Japanese contractual governance model is nevertheless relevant to American problems. Three conditions are central to our model of contractual governance: a productive relationship among the participants; the need for relation-specific investment; and the presence of substantial product market competition. The first condition provides the context; the second creates the problem; and the third causes the coalition formed by cross-holdings among factor providers to reject a shared commitment to the quiet life. America's high technology industry seems an obvious candidate for contractual governance initiatives. Joint venture and equity participation have already become familiar, ${ }^{119}$ and the difficulty of technology transfer makes relation-specific investment important. ${ }^{120}$ Moreover, an established group of venture capital investors already play roles similar to Japanese main banks, in particular those of crisis monitoring and privatization of bankruptcy, by

117. Berkshire Hathaway takes large stock positions. While Berkshire's senior managers often become members of the portfolio companies' boards, their visible activity has been limited to times of crisis, as at Salomon Brothers after the Treasury bidding scandal.

118. For a rejoinder to Jensen, see Alfred Rappaport, The Staying Power of the Public Corporation, HARV. BUS. REV., Jan.-Feb. 1990, at 96.

119. See WILLIAMSON, supra note 56, at 158-59; Pisano, supra note 66.

120. See WilliamSon, supra note 56, at 293-94; David J. Teece, Economies of Scope and the Scope of the Enterprise, I J. ECON. BEHAV. \& ORG. 223 (1980). 
facilitating a single voice for numerous suppliers of capital. ${ }^{121}$ Finally, competition among products and between technologies is vigorous.

We realize that high technology is currently one of the American economy's best performers, for which contractual or corporate governance improvements may now be unnecéssary. Heavy industries-like autos and steel-are in worse condition and seem to have serious governance problems. Here too our prescriptions might fit. If each is slow to develop new technologies and production methods, cross-ownership among relational suppliers might speed adaptation. So, if new steel technologies—say, the mini-mills-are to be located near new auto plants having innovative production technologies, cross-ownership might function in a manner similar to that which we hypothesize for Japan. Each will double up their interest in the other's prosperity: steel firms will want a better customer and a better portfolio firm. Information that the firms will gather about each other while adapting the production process together may make each a more valuable stockholder to the other. Moreover, competition, which we hypothesize is necessary to prevent mutual shirking, is today generally present in both industries (to the extent that import restrictions are not severe).

Our point is neither that the existing organizational structure in high technology industries mirrors Japanese contractual governance nor that parallel technological changes in related industries like autos and steel make them ripe for cross-ownership; we have not undertaken this inquiry, and our views are not so deterministic. Nor do we claim that American legal, tax, and financial structures are ready to support cross-ownership. We do suggest, however, that comparative analysis of the Japanese contractual governance model may lead to the instrumental use of such a governance structure in the United States, transplanted to where the structural economic preconditions to successful domestication are in place.

\section{CONCLUSION}

Too many efforts to understand the Japanese system have suffered from Berle-Means blinders. Hidden by the focus on main banks is the fact that one-third of the cross-ownership is held by industrial companies. ${ }^{122} \mathrm{We}$ hypothesize that cross-ownership reduces the risk of opportunism when parties make large relational investments. The management of any factor that defects, by trying to raise price inordinately, to skimp on quality, or to miss the next technological step in the industry, will face a coalition of stockholders. Fear

121. See Christopher B. Barry, Chris J. Muscarella, John W. Peavy III \& Michael R. Vetsuypens, The Role of Venture Capital in the Creation of Public Companies: Evidence from the Going-Public Process, 27 J. FIN. ECON. 447, 449-51 (1990); William A. Sahlman, The Structure and Governance of Venture-Capital Organizations, 27 J. FIN. ECON. 473, 475-87 (1990).

122. This amount increases when one attributes the bank's industrial portfolio to the other members of the keiretsu. 
of such a confrontation deters defection. Product market competition keeps the system from lapsing into a conspiracy of passivity.

Industrial cross-ownership has not previously been emphasized as a key element of the Japanese corporate system, and we believe this connection is important. Indeed, we suspect that some of the main bank interventions can and should be.seen not just as the pure intervention of the residual equity holder (or large creditor) to protect its investment-the American model-but as the intervention of factor providers. The bank monitors directly by providing credit and indirectly by serving as agent for the other factors. The bank assumes this agency role partly because of its stock ownership in the other factors.

The existence and persistence of such a system strongly supports the view that the American system of corporate governance is not inevitable, but is instead contingent on the accidents of American financial organization and political history. The newfound activism of some financial intermediaries and the rise of the LBO association also support this general proposition. But neither the newly-active intermediary nor the LBO replicates the Japanese system in its specifics. Finally, although the Japanese system may provide general deterrence to keep managers faithful, this system has not yet shown itself to be an effective substitute for the American takeover of the 1980's. The Japanese main banks have yet to face the widespread cash flow and conglomerate problems that pervaded the targets of these takeovers. The Japanese system tells us generally that there is more than one way to build a large corporation. It tells us little, however, about whether and how American financial intermediaries should be unleashed. 